Policy and funding

\title{
Not yet back to basics
}

THE present apparatus for science policy development and funding in Finland was established in 1969 and added to in 1983 when a parallel infrastructure for technology research was set up. Having realized relatively late the need for an organized science and technology research policy, Finland is working hard to make up for lost time.

Over 75 per cent of research in Finland is financed by two ministries. The Ministry of Education funds universities and institutes of higher education directly and also funds basic research indirectly through the Academy of Finland. The present Academy, restructured in 1969, consists of seven research councils and a Central Board of Research Councils. The Academy has become the principal organ for development and implementation of basic research. This year, the Ministry of Education will spend FIM 1,052 million on research, 23 per cent of

21 per cent of the total state research budget for 1987 .

The practice of basic research funding follows a common pattern. The research councils of the Academy of Finland receive applications from faculty members of universities and research institutes, and then award project grants, on the basis of merit, for fixed periods. In addition, the Academy supports some 600 research posts at various levels.

Development of science policy and planning started in Finland in 1963, when the Science Policy Council was set up. Renamed the Science and Technology

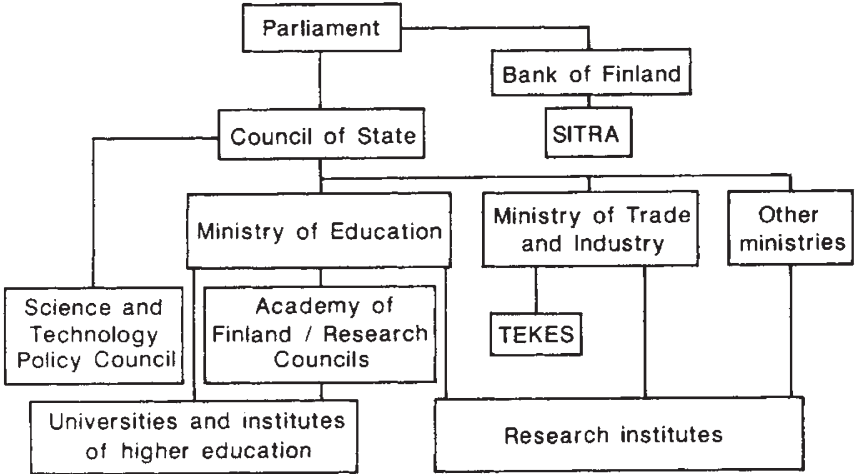
which will go to the Academy of Finland.

Most of the remaining government expenditure on research and development (almost 40 per cent of the total state research budget) is routed through the Ministry for Trade and Industry. In 1983, the Technology Development Centre (TEKES) was set up by Act of Parliament to plan and allocate state funding for technology research. It coordinates links between universities, institutes and industry, with an overall aim of promoting the international competitiveness of Finnish industry, largely through grants and loans for goal-oriented research. This year, TEKES's budget increased by 13 per cent to FIM 425.5 million. The Ministry of Trade and Industry and TEKES also provide about 25 per cent of the budget for the Technical Research Centre of Finland (VTT), the largest technical research institute in the Nordic Countries.

The Finnish National Fund for Research and Development (SITRA) is a third source of research funding, set up in 1967 to commemorate 50 years of Finnish independence. It mainly finances development of industrial production in high risk areas and, in 1984, gave out awards totalling FIM 68 million.

As Finland is a neutral country its spends little on defence research. The Ministry of Defence research and development budget for 1987 is FIM 47.5 million. Research spending by a combination of other ministries accounts for about
Policy Council in 1987, it assists the Council of State (the government's highest executive body) and its ministries in issues related to science and technology. The Council is chaired by the Prime Minister and its membership comprises the ministers most concerned with research and representatives from the Academy of Finland, TEKES, research, higher education and industry.

In its current programme, running until 1990, the Science and Technology Policy Council is concerned with four main trends: ensuring constant growth of research and development, achieving a better balance between growth and development, researcher training, and internationalization of Finnish research. It is up to the Academy of Finland and TEKES to translate these into specific initiatives.

Elisabeth Helander, research director of the Academy of Finland, explained the need to monitor growth in research: "Finland spent only 1.2 per cent of gross domestic product on R\&D in 1985. This year, it will spend 1.7 per cent and the goal set by the previous government is 2 per cent by 1990 , giving Finland the highest growth rate in research spending of any OECD small country". The proportion of the overall national research budget allocated for basic research has, however, shown a net decline over the past decade. The growth therefore reflects an increase in state investment in applied research.

\section{The Finn red line}

"Polar bears don't walk the streets of Helsinki, we are not communists and nobody speaks Russian". These words may be found in tourist guides distributed to Finnish hotels, but also spring readily to the lips of scientists and administrators faced with a foreign journalist who wants to write about their country.

Finns are sensitive about their border with the Soviet Union, pointing to the lack of affinity between the two countries. From the twelfth century until 1809 , Finland was a part of Sweden. Even today, 300,000 Finns (6 per cent) have Swedish as their mother tongue and the country is officially bilingual. There is even a Swedishlanguage university (Abo Akademi) in Turku. Government from Russia lasted only a century. In 1809 Finland was made an autonomous Grand Duchy, ruled by the Tsar of Russia, until attaining its independence as a republic in 1917.

After the Second World War, Finland lost part of its territory (Estonia and Karelia) to the USSR but prides itself on having never been occupied. With war damages to pay to the United States until the early 1950s, Finland developed a neutral foreign policy that persists today.

Finland's modern front door and facade may face west, but the back door opens onto 8.5 million square miles of Soviet Union. If Finland is the Western department store most accessible to the Soviet Union, the USSR offers energy resources, world-class theoreticians, especially in mathematics and physics, and a ready market for Finnish high-tech exports.

There are attempts to redress the balance between growth and development and to redirect more money to basic research, especially in the universities. "The second ten-year Development Law, passed by Parliament last winter", says Esko-Olavi Sepälä, the Science and Technology Policy Council's chief planning officer, "was accompanied by a government decision to give universities a real budget increase of 15 per cent per year for the next four years". This new money is intended for research and also to improve training, by increasing the number of places and decreasing the time it takes to complete a PhD (see next page).

One of the major aims of the current programme is to increase the 'internationalization' of Finnish science and technology. The Academy of Finland plays a significant role in this effort, both by providing funds for researchers at all levels to travel abroad and by its membership of European projects. Similarly, TEKES has increased its role in promoting international contacts, for example through the European Space Agency, of which Finland became an associate member this year. 